\title{
Financing Research Universities in Post-communist EHEA Countries
}

\author{
Ernő Keszei, Frigyes Hausz, Attila Fonyó and Béla Kardon
}

\section{Introduction}

A great number of economists and other experts have written papers and books in the last 50 years concerning the funding of higher education (see e.g. citations in Woodhall 2007), but almost all of them seem to ignore a UN document that is adopted and ratified in most countries of the world, thus it is considered as a law in action. Article 13, Section 2, (c) of the International Covenant on Economic, Social and Cultural Rights tells that "[the States Parties to the Covenant recognize that, with a view to achieving the full realization of the right of everyone to education] higher education shall be made equally accessible to all, on the basis of capacity, by every appropriate means, and in particular by the progressive introduction of free education" (UN 1966; italicized by the authors). Of the 47 member countries of the EHEA, 43 have ratified this Covenant, except for Andorra, the Holy See, Moldova and the FYRM. While-in accordance to 2, (b) of the same Article-secondary education in almost all countries have been made free for anyone (even partly compulsory in most of the countries), the tendency in higher education seems to be the opposite, also in most of the EHEA countries.

\footnotetext{
E. Keszei $(\bowtie)$

Eötvös Loránd University Budapest, Budapest, Hungary

e-mail: keszei@chem.elte.hu

F. Hausz · A. Fonyó

Corvinus University of Budapest, Faculty of Social Sciences, Budapest, Hungary

e-mail: frigyes.hausz@gmail.com
}

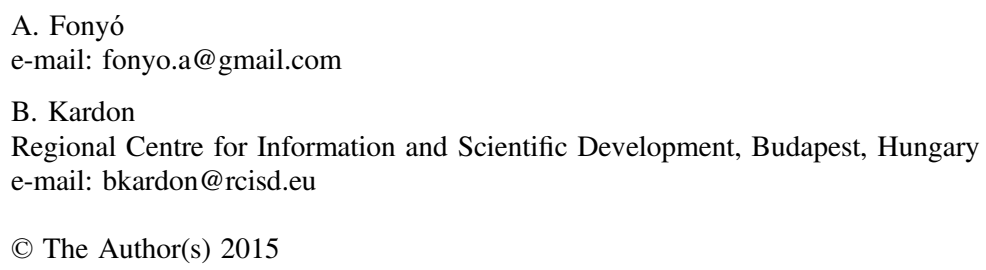


A highly esteemed document concerning the status of modern universities is the Magna Charta Universitatum, endorsed in Bologna 18 September 1988. The first point in its Preamble states that "at the approaching end of this millennium the future of mankind depends largely on cultural, scientific and technical development; and that this is built up in centres of culture, knowledge and research as represented by true universities". The main text also emphasizes - at several occurrences - the importance of research as an inherent part of university activity. Thus, a university cannot properly function if its scholars are not active in scientific research, and the future of mankind also depends on a healthy functioning of research universities.

An important initiative of the European Union has been to promote the formation of a European Research Area (ERA), which is more formal in its structure than the EHEA, comprising EU member states and a few associated countries. The Framework Programs for Research and Technological Development of the EU contributed to the development of research and innovation in Europe. Within the 7th Framework Program, the ERA has been formed, and a new ambitious framework program-Horizon 2020 for the period of 2014-2020 - aims to further increase the global competitiveness of ERA. A combined effort of the Max Planck Society and selected European universities and research organizations resulted in a white paper during the planning period of Horizon 2020 which called attention to an unbalanced regional competitiveness regarding research potentials throughout the ERA (MPS 2012). It states that "Europe is being held back by persistent disparities in its research and innovation capabilities which are the key to future prosperity. ... Yet many EU countries and regions, often with distinguished traditions of achievement in science, lack the high quality research capacity adequate to the challenges of today and tomorrow."

It is precisely this lack of high quality research capacity that is in focus of this chapter. After a brief historical overview on funding of HEIs, relevant statistical data will be shown to support the unfavourable situation of research universities of distinguished tradition of achievement in science in some post-communist Eastern Central European countries. After an analysis of the data, it is shown that efficient policies must be put into practice in order to ameliorate the perspectives of the research universities and the countries of the region concerning research, innovation and competitiveness.

\section{Historical Overview}

The origin of the first institutions which became modern European universities dates back to the 11th-13th century (a very concise discussion can be found in Dmitrishin (2013); for a detailed account of the history of European universities see the four volumes of Ridder-Symoens (1992-2010); in a shorter version in Wittrock (1993). Though these universities have quite diverse origins - including also some of them founded and managed by students - sooner or later, the majority of them have been chartered by sovereigns and the pope as well. There were a considerable 
number of HEIs founded by the Catholic Church or by its institutions (the Jesuit Order played a paramount role in these foundations), which typically have been donated at the beginning of their history some endowment and properties that could be used for the financial needs of their operation. In most cases, sovereigns also donated properties for the same reason. During the 17th and 18th century, enlightened absolutism led to a state-determined government of the HEIs, and in many cases, additional donation of properties or endowment (or both) provided the means to cope up with the more rigorous standards prescribed by the state.

The most determining revival of European universities was a result of the reformatory ideas developed by idealistic scholars in Germany around 1800, which later became known as the idea of the Humboldtian university (Paletschek 2001). The exemplary "prototype" is the Berlin University founded in 1810, which, since 1949, holds the name of the Humboldt brothers. Determining features of this reform were that universities are genuine research institutions with the unity of research and teaching, and that the "academic freedom" consists not only of the freedom of teaching, but also that of research, which allows furthering pure science. Another feature of the new idea was that universities should prepare students for a humanistic role to serve mankind and also the state. An important implication of these reforms was that the state should be responsible to support both teaching and research at HEIs (Humboldt 1810). As a result of social and economic changes - e.g. the industrial revolution - the number of students and the need for research also increased during the 19 th century. In addition to the construction of new buildings to accommodate the increasing number of students and the emerging research activities, the state also supported universities by direct subsidies, as their former resources were not sufficient to cover the costs of functioning according to new needs. With this more direct financing mechanism, state administrations vindicated a more direct influence on the management of universities as well. The 19th and 20th centuries have seen a continuous debate between the ministries responsible for education and the HEIs to interpret the sacred principle of "academic freedom". However, the typical situation in Europe was that, until the late 20th century, direct state subsidy became the determining - if not the only-source of university budgets.

A new epoch of higher education history began after WW2, with an ever increasing "massification" of higher education. This happened earlier in the US than in Europe, and earlier in Western Europe than in the Soviet-allied Eastern countries. In these latter countries, massification only occurred after the disintegration of the communist system. In addition to the great increase of the number of students, costs of scientific research have also increased in this period in a substantial way. Most of the countries could not provide the necessary financial support for higher education, thus many alternative forms of financing HEIs had been put forward, and also implemented (for a review, see e.g. Salmi and Hauptman 2006; Woodhall 2007). A recent complication of this situation has been the global economic crisis. The great social demand for many other services to be financed by the state does not allow for sufficient support of higher education in many countries.

Eastern European post-communist countries have suffered the greatest disadvantages during the last 70 years compared to other regions having traditional 
universities. Communist takeover of power after the Soviet occupation, at the end of 1940s, led not only to a strict political and administrative control of the HEIs, but also to confiscation of their properties and loss of their endowments. As a result, total communist party control and completely state-budget dependent funding had replaced the partly independent funding and considerable academic freedom. In addition, research activity has been rechanneled to newly formed research institutes of the Academies of Sciences following the Soviet model, and universities have been left with little research, and a very low research budget. (In most countries, this separation of research and teaching survived to a certain degree until today.)

To illustrate this change, let us recall the fate of the endowment of the oldest surviving Hungarian HEI, nowadays called Eötvös Loránd University (Rácz 2010). At the time of its foundation, it was a Jesuit university, and the founder, Cardinal Péter Pázmány bequeathed an endowment of 100,000 Florins $^{1}$ to cover the costs of the institution. When adding a Faculty of Law to the other two faculties (and thereby transforming the institution into a proper university of the time), two later cardinals donated altogether an additional sum of 37,000 Florins to the institution. In addition, the cardinal of Hungary topped up the endowment with a yearly 10,000 Florins. At the inauguration of a Medical Faculty, Empress (and Hungarian Queen) Maria Theresa donated a great land property that previously had belonged to a rich monastery in central Hungary. After the dissolution of the Jesuit order by the pope in 1773, numerous large properties of the order have also been donated by the Empress/Queen to the university, and the entire capital of the Nagyszombat ${ }^{2}$ Jesuits has been added to the endowment of the university. Even after the Versailles Treaty, when many of the properties of the university remained in territories of the newly formed Czechoslovakia, The Hague International Court made the decision in 1933 that the Czechoslovak state should pay a compensation for the loss of the properties of the university. The compensation for the 9200 ha land was enough to buy another piece of land of 4700 ha within the post-Versailles Hungary. All these properties and the entire endowment were lost after WW2, and the university became fully dependent on state subsidy.

The fate of other universities in the Soviet-allied countries was quite similar. Thus, they faced the formation of a market economy after the fall of the Soviet Union, without any alternative means of financing their activity than direct subsidy. The region's states after democratization and reorganization of their economy and budget structure had many challenges that needed financial means. After the 1990s, an initial increase in the educational budget was inevitable due to the late massification of higher education, but in most of the countries of the region, this tendency did not continue after the turn of the century, while the number of students in the tertiary education still increased.

\footnotetext{
${ }^{1} 1$ Florin at that time was the equivalent of about $110 €$ at current price.

${ }^{2}$ Nagyszombat is actually Trnava, in Slovakia, where the university has been founded and operating from 1635 till 1780 .
} 


\section{Comparative Study of Some HEIs from Different Countries}

Though a vast literature is available on higher education financing, authors typically do not deal with funding research at the institutions, rather with different financing models concerning the sources of higher education budget. It is also difficult to find reliable data sources concerning research expenditures of HEIs. This is the reason why we have chosen to collect available actual budget data of some traditional research universities that can be found on their websites. As basic facts about their students and staff, as well as their total budget are typically readily available, we decided to collect data on the number of educational-scientific staff, the number of students, and the total operating budget of the institutions. A typical indicator in current literature when comparing the intensity of higher education financing in different countries is the expenditure per student in tertiary education (see e.g. OECD 2011). However, this indicator is not necessarily related to the intensity of research, rather to the intensity of the educational activity. Therefore, we decided to compare research intensity of HEIs in different countries based on the expenditure per academic-scientific staff member, which is an easily available indicator. At traditional research-intensive universities, practically every academic staff member is expected to actively participate in high-level scientific research; thus this is a suitable indicator to give information at least on the order of magnitude universities spend for research. Preliminary data collection clearly indicated distinct regions from the point of view of research funding at HEIs. For this study, we selected traditional research universities present in international rankings, having the best rankings in their home countries, whose data mentioned above are listed in Table 1.

A striking feature of the data is that the selected regions are markedly different concerning research budgets at universities. Looking at the normalized values of yearly university budget per academic staff, normalized to the smallest value of the Cracow Jagellonian University, we can distinguish the following groups.

In the US, this indicator is in the range between 20 and 60, private universities usually having a larger value. The next category is Eastern Asia, where the indicator has a value close to 20, except for Taiwan. Western European Universities fall between the values of 5 and 8, Ruprecht-Karls-Universität in Heidelberg having somewhat lower a value, but it might be due to its different structure from the others listed. The last and least financed category comprises Eastern European Universities, close to the base value of one. Concerning the University of Vienna, its value is closer to those of the universities in the post-communist countries than to Western European ones. Among the four post-communist country universities, we can also find two categories that differ by a factor of two in the research intensity indicator. Charles University Prague is the best performing research university in the Czech Republic, and it is financed according to an output-based system of the country. Warsaw University is a beneficiary of prioritized financing of HEIs in Poland, also from European Structural Funds. Similar initiatives can be found neither in Austria, nor in Hungary. 


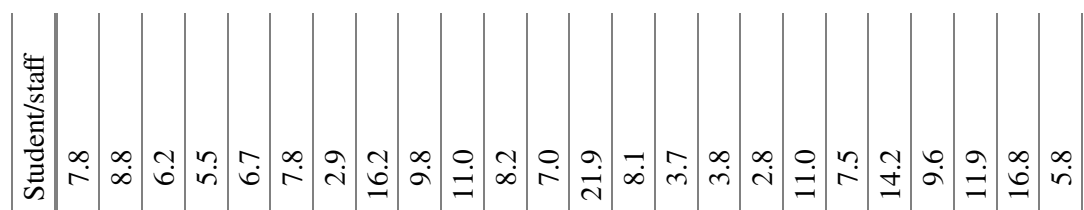

荌

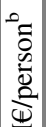

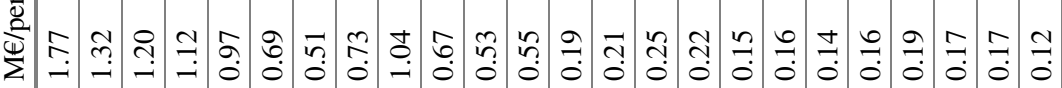

穿

:

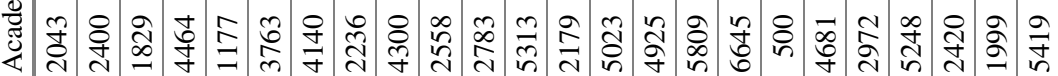

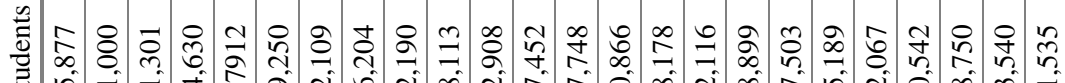

जी

焉

를

힐

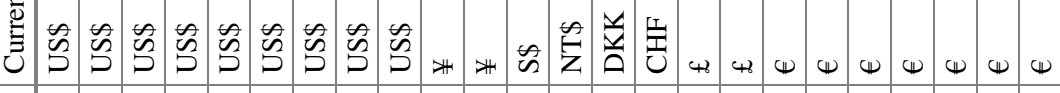

पे

离 $\stackrel{\Xi}{\bar{\Xi}}$

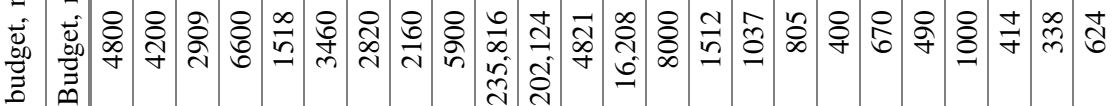






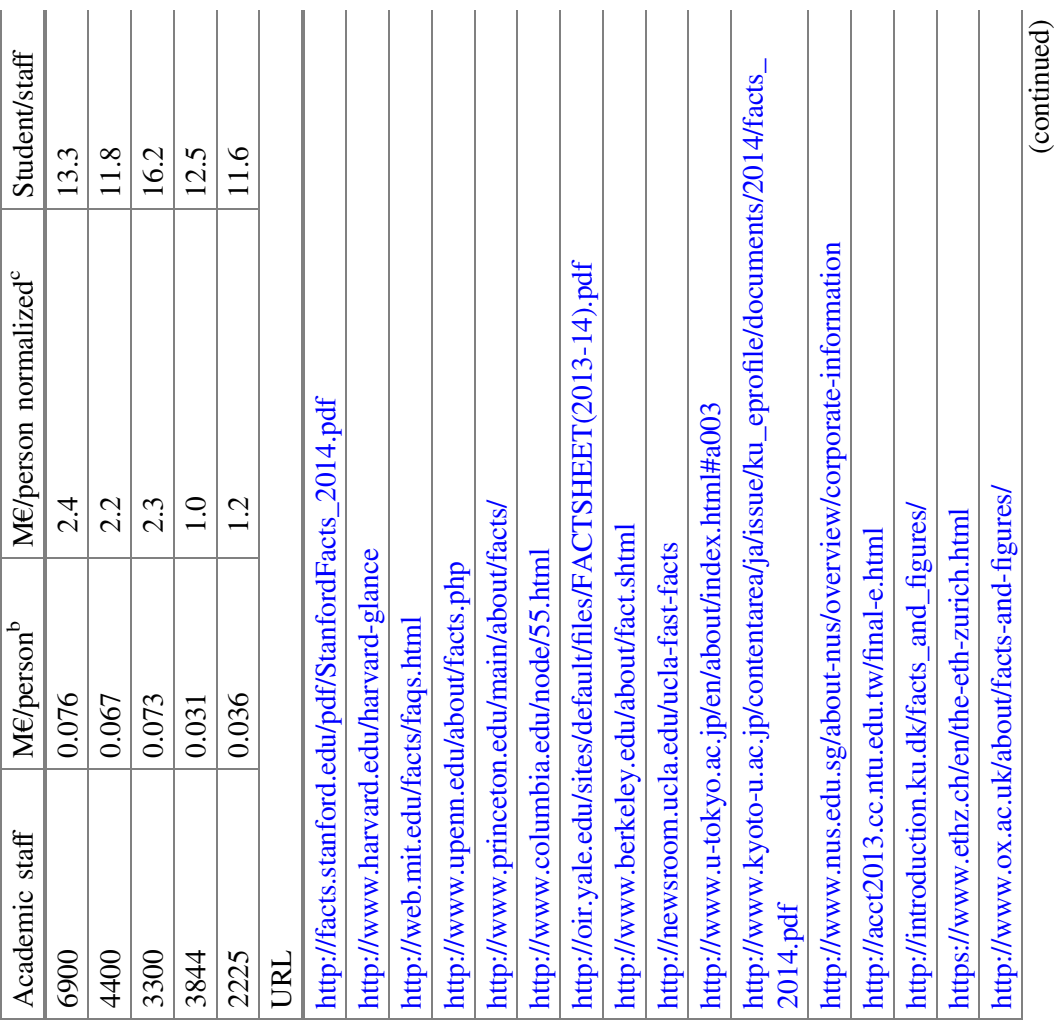

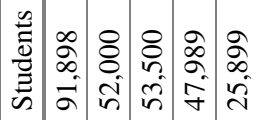

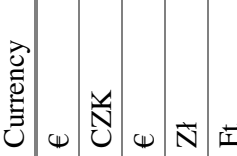



胥

总

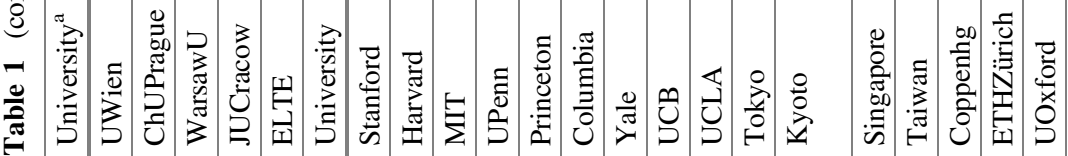




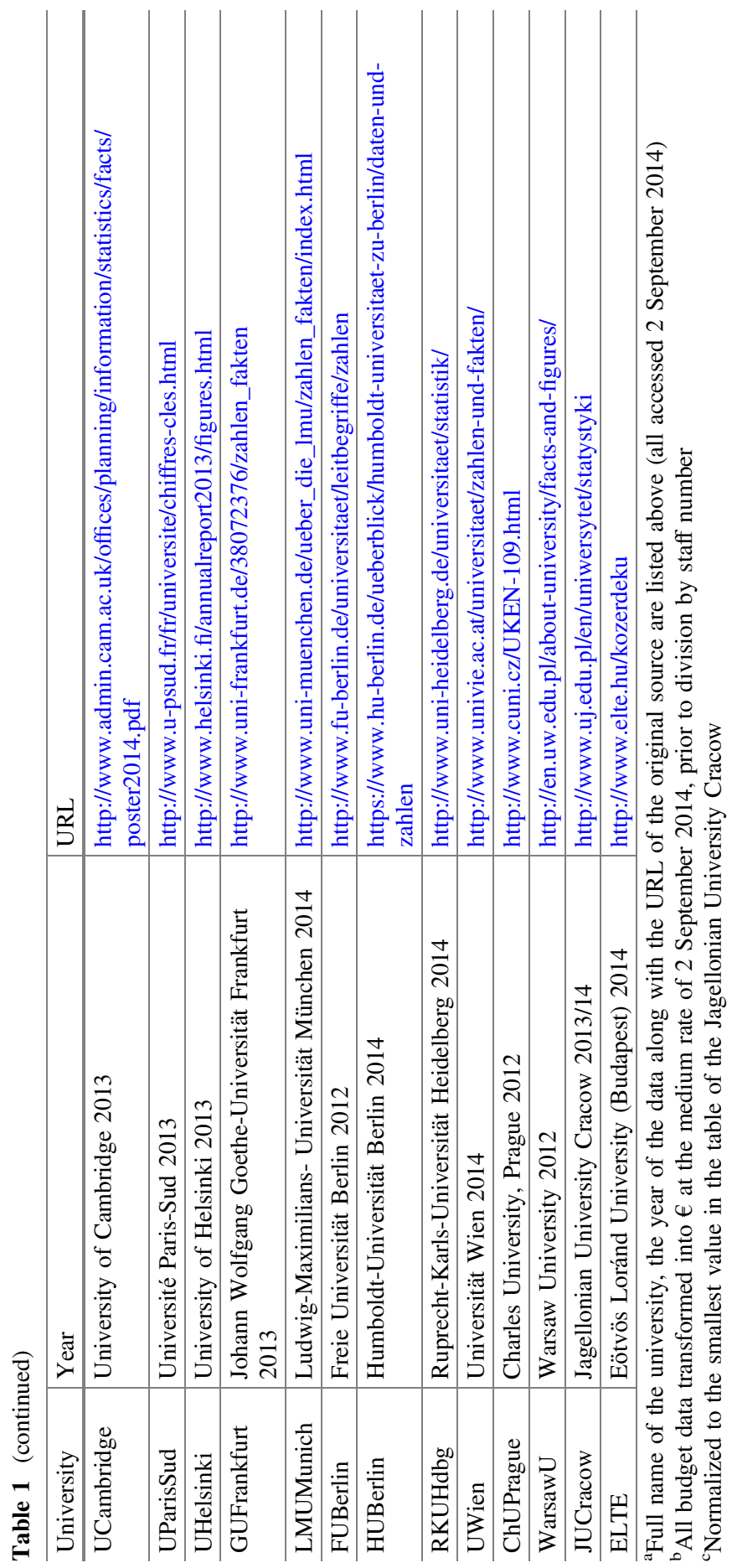




\subsection{A Detailed Insight into the Hungarian R\&D Financing in Higher Education}

As a case study of the rather poor financing of Eastern European research universities, we would like to explore the case of Hungary. Similarly to all other Soviet-allied countries, HEIs have had limited R\&D infrastructure by the dawn of the new era following the fall of Soviet Union, leading to the sovereignty of the countries and democratization of their society and economy. Another peculiarity of the R\&D and HE systems of the Soviet-allied countries was that research has been allocated to a large extent to the academies of sciences running research institutes, rather than to HEIs. As a consequence, HEIs in the early 1990s did not have the necessary means to fulfil the expectation of a good balance between education and research. National authorities did realize this contradiction, and-in many post-Soviet countries - tried to adjust this balance accordingly.

In Hungary, the first government following free elections in 1990 also realized this handicap and signed a contract with the World Bank to receive a Structural Adjustment Loan (SAL) of which US\$66 million, with an obligation to add another 5.5 billion HUF (the equivalent of cca 40 million US\$ at contemporary course) have been allocated to the development of higher education (Kotán and Polónyi 2003). Though the contract contained several policy conditions on the loan, the committee charged by the government spent approximately $80 \%$ of this sum for the development of research facilities at Hungarian HEIs (which was roughly $60 \%$ of the total yearly budget of HEIs at the time). This initiative resulted in a humble but real "catch-up" of the HE sector concerning R\&D potential.

Another development action in HE is associated with a second World Bank loan concerning modernization in Hungary. It has been signed in 1998, and most of the content of the policy agreement concerning higher education focused on new buildings and structural changes in the Hungarian HE system. Due to several reasons - mostly to the availability of much better loan conditions in the aftermath of the contract - the contract has been terminated by the Hungarian government before completion. The roughly 100 million US\$ (cca. $22 \%$ of the total yearly budget of HEIs at the time) has been spent for several purposes, but not really for the improvement of the R\&D infrastructure (Kotán and Polónyi 2003). Thus, it was the first SAL in 1990-1994 that resulted in a considerable improvement of the research infrastructure in HEIs, and-as we will show-there wasn't another possibility to substantially improve the poor infrastructure of research in HEIs in Hungary ever after.

When trying to give a realistic picture of the R\&D budget of HEIs, it turns out that it is not an easy task, as budget reports of universities are not really clear-cut in this respect, in the sense that research incomes as well as expenditures cannot always be distinguished from other (educational and general operational) costs. Concerning the sources of the budget, direct state subsidies already contain some contribution to research expenditure, and there are other resources for research purposes as well. 
Let us discuss first recent direct state subsidies. According to Act CCIV of 2011 on Higher Education as well as the previous Acts, the state had to subsidize scientific development in higher education institutions (Act CCIV 2011, Section 84 (2)). Accordingly, during the years 2008-2012, Hungarian HEIs were entitled to receive normative funding earmarked for R\&D activity (Central Budgets 20062013), which was roughly $15 \%$ of the total direct state subsidy - the equivalent of some 108 million $€$. However, this funding was input-based, and part of a block-grant. Thus, even if it had been earmarked for R\&D when allocated, HEIs usually spent a large part of it for operational costs of educational activity as there were no incentives coupled to the improvement of research. As a result, this non-negligible amount did not really help to improve research activities of HEIs. To accommodate legislation to the usual habit of HEIs, the HE Act has been changed, and the R\&D-aimed part of the subsidy of 13.55 billion HUF for the year of 2013 has been added to an integral block grant, without earmarking its R\&D share. As to its actual use, there are no reliable data available. Due to the bad financial situation of the HEIs, they probably have spent most of it again for other purposes than research.

Also in 2013, a system of performance based excellence awards was introduced to support R\&D activity. Constructed upon similar principles as the German "Excellenzinitiative", 3 a Hungarian program for institutional excellence was launched; from 2013 on, Hungarian higher education institutions can be awarded excellence titles based on their performance. A total of 10 billion HUF (the equivalent of some 32 million $€$ ) from the national budget was exclusively dedicated for the support of institutions in 2013 that have been considered outstanding based on their performance indicators in their main fields of activity (Central Budgets 2006-2013). According to the 2014 Central Budget, a similar sum is foreseen for the title holding institutions. However, state subsidies for the HEIs that have the excellence titles did not change much altogether, as there were austerity measures for the fiscal consolidation of the state budget which resulted in cuttings also to the HEIs; i.e. a trend to reduce HE and R\&D expenditures (Széll Kálmán Terv 2011). Allocations due to the excellence initiative hardly compensated for the decrease of the general state subsidies.

Due to the historical heritage of a large network of research institutions operated by the Hungarian Academy of Sciences (HAS), these institutions are great competitors to absorb state subsidies and other national resources for R\&D. (Their combined scientific output is comparable to that of one of the three largest universities. ${ }^{4}$ ) On the other hand, HAS and its research institutes also cooperate with the actors of HE in several respects. The Academy runs programs to support research groups at the universities, and runs the successful brain-gain Momentum

\footnotetext{
${ }^{3}$ See http://www.dfg.de/en/research_funding/programmes/excellence_initiative/general_information/index.html.

${ }^{4}$ See the science maps of Hungarian R\&D output: http://www.hungarianscience.org/maps_aggreg_ 20072011.php.
} 
Program for the support of excellent Hungarian researchers who return from abroad to Hungary. Though this latter program supports in a large part researchers working at the HAS research institutes, a considerable share of these researchers get support from the HAS budget but work at universities.

A humble but important contribution to funding basic research in Hungary is The Hungarian Scientific Research Fund (Hungarian acronym: OTKA) that has been the major funding agency of basic research and related scholarships since 1986. OTKA allocates financial support for research projects, and has a budget of 7686 billion HUF in 2014 (Central Budget 2014). At least half of its support goes to HEIs, but it is only slightly higher than a mere $1 \%$ of the total yearly budget (including non-state-subsidy sources) of HEIs. ${ }^{5}$

Summing up, direct state resources for higher education R\&D purposes have decreased in the past few years. Though additional national budgetary sources are still available for higher education institutions, these are also available by other institutions as well, either as grants or tender calls of different funding agencies. Whether new programs could compensate for the abolition of the normative funding cannot be answered with full certainty; however, the current state of financing obviously has a negative effect on the R\&D activity of HE institutions.

A determining feature of $R \& D$ development in Hungary-similarly to other countries in the region-is a strong dependence on the financial support coming from the European Structural Funds. During the 2007-2013 programming period, through the framework of the Social Renewal Operational Programme (SROP), Hungary allocated 107 billion HUF from the European Social Funds to support the development of the higher education system, and to strengthen the infrastructure and human resource capacities of higher education research activity (SROP 20072013). The annual average funding reached 15 billion HUF-almost $50 \%$ of state subsidies for HE R\&D, and approximately the double of the total yearly budget of The Hungarian Scientific Research Fund (Central Budget 2014). In addition to the measures of the SROP, enterprise-focused projects within the framework of Economic Development Operational Programme (funded by the European Regional Development Fund) also offered participation opportunities for higher education institutions, but related data are not available at the time of the submission of this chapter. Measures of the SROP aimed at strengthening R\&D capacities of HEIs to enhance their access to alternative sources of funding. This operative program can be considered as a success; $R \& D$ capacities of institutions have expanded, and a positive correlation was found between development measures and the acquisition of third party funding (Kutatóintézet 2013). It is interesting to quote the final conclusion of this part of the study: "The higher the support per academic staff [within these development measures], the higher the increase in acquiring other national and international R\&D funds".

\footnotetext{
${ }^{5}$ OTKA ceased to exist as an independent agency from January 2, 2015 and became part of a central government agency responsible for a coordinated distribution of all public R\&D funding, called National Research, Development and Innovation Office, created by the Act LXXVI (2014).
} 
It is easy to conclude that the Structural Funds played a crucial role in strengthening Hungarian R\&D capacities at HEIs. Eligibility in the system of Structural Funds, however, is based on the development level of regions (NUTS2). Given that the Central Hungarian Region belongs to some of the most advanced regions of Europe, the amount of available resources is very limited, and will be even less in the future. The fact, that the Central Hungarian Region is the most R\&D intensive region of the country-almost $50 \%$ of all higher education capacities and two thirds of all R\&D capacities are concentrated in the capital and the surrounding region - the lack of available resources poses a significant threat. At the beginning of the programming period, some SROP measures could have provided supplementary funds to the Central Hungarian Region, but from 2012 on, state funded measures (using the Research and Technological Innovation Fund) were to set up to compensate for the lack of EU funds. However, their volume was much less than the loss in European funds. To evade a significant threat to the competitiveness of the country, higher education development strategies must be designed in a way that builds upon the synergies of possible funding sources.

Though the Framework Programmes for Research and Technological Development only contribute less than $7 \%$ to the total European R\&D expenditures, they provide a considerable help for the Hungarian HEIs to support their research activity. Among the new member states, Hungary is ranked second in the number of accepted project proposals, and Hungary received the second largest amount of funding (after Poland) among these countries. Higher education institutions acquired $31 \%$ of all these funds received by Hungary between 2007 and 2013; out of the total amount of 224 million $€, 69,2$ million $€$ was utilized in HEIs

\section{EU contribution to retained projects}

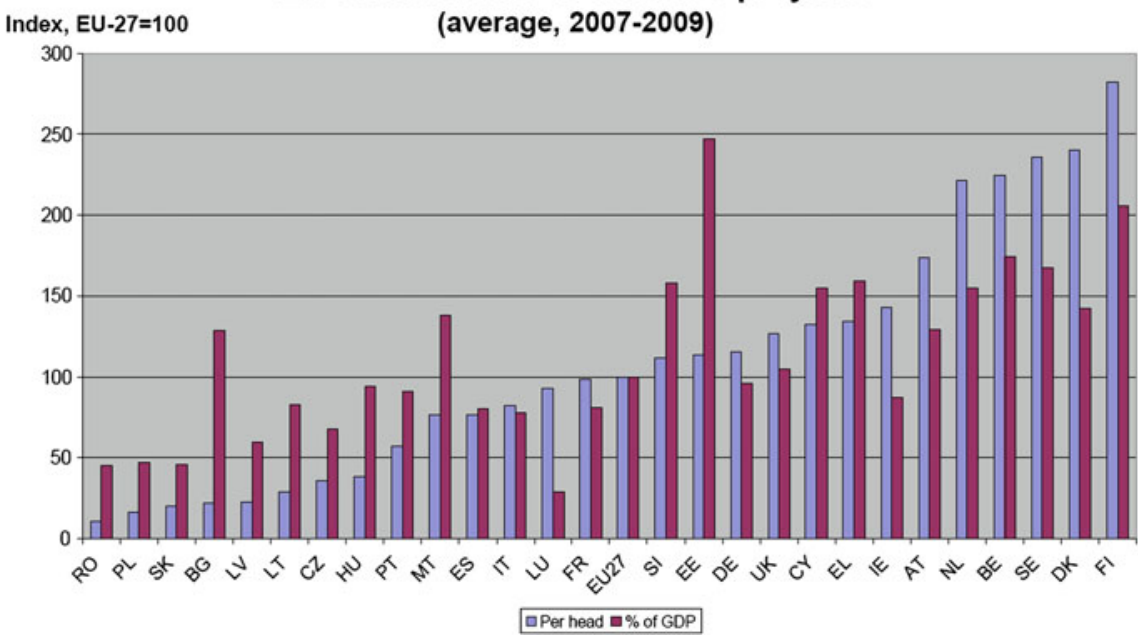

Fig. 1 EU member state contribution in the retained FP7 projects relative to population and relative to GDP of the respective countries (Source EC 2010) 
(NIO 2014). However, to correctly interpret this data, it must be mentioned-as the interim evaluation of FP7 (EC 2010) revealed-that the performance of new member states - based on the number of inhabitants or economic influence - in the Framework Programme is still lagging behind the performance of older member states (see Fig. 1). The number of projects launched with participants from the new member states is significantly lower, and the average amount of funding for consortia members is also dramatically lower (less than $50 \%$ ) than in the case of other member states (EU15). The rate of success is also smaller in new member states. Despite of this low share, Framework Programmes are of great help for HEIs in Hungary, as well as in other post-Soviet countries in Eastern Europe.

\section{Conclusion and Recommendations}

From the documents cited in the introduction concerning the role of higher education institutions in the economy and society, we can conclude that higher education-including research done in HEIs - is a public good for the benefit of the whole of mankind, and also for the countries which host the HEIs. Though the International Covenant on Economic, Social and Cultural Rights is a law in action in the vast majority of the EHEA countries, its obligation to the progressive introduction of free education in HEIs seems not to be followed, except in a few countries. Even if we realize that, for the time being, within the present economic situation of the states, this goal is not realistic on a short term, states should be responsible to guarantee that HEIs can have the financial means they need to fulfil their important mission. The present trend to provide this financial means is cost sharing between different actors in the field of higher education.

Scientific research, or in a broader sense research and development, is a special kind of activity in HEIs due to its need for extremely expensive infrastructure and an extensive demand in human resources. Though research is a substantial element of the training procedure, its practice as well as its goals are beyond mere educational needs; thus it is necessary to involve other financial resources in addition to those which aim to support education only. Regions of the world where this R\&D activity is at high level are privileged, and typically develop so that they are able to successfully face economic and societal challenges. Obviously, it is a global interest not to let any regions lag behind too much concerning necessary resources to maintain a stable society. It is therefore desirable within the EHEA also, that a reasonably balanced regional development be achieved.

In this chapter, we have focused on the situation of the R\&D potential of HEIs within the post-Soviet Eastern European countries. Analysis of the data presented in the previous sections is not easy, but we can state some simple principles. We have tried to find robust indicators that can show important differences in the research intensity between traditional research universities in various parts of the world. The total operating budget per academic-scientific staff is an easily available and robust indicator. If there are big differences in the order of magnitude of this indicator, they 
should be associated with a markedly different financing of the research activity. Obviously, differences in the operative costs spent for buildings, management and the basic staff providing services for education account only for a smaller part of the difference. The largest portion of the higher operative budget is expended by the institutions to support R\&D activity.

Accordingly, from the point of view of research intensity, we can distinguish four regions of the world where traditional research universities can be found. The best financial situation is characteristic of North American research universities. Roughly, a financing less by a factor of two characterizes Eastern Asian universities. A factor of four to six less in budget is typical for Western European leading universities, while the budget of the best Eastern European research universities is a factor of twenty to forty less than that of their US counterparts. Considering the EHEA only, there are typically three- to eightfold differences between Western and Eastern universities. Obviously, this is an undesirable situation concerning regional balance both in higher education and research. If there aren't some specific measures to mitigate this imbalance, Eastern universities will lag behind even more, as a low research potential also means a great handicap to win research projects from various resources.

As we have shown on the Hungarian example, even relatively modest "injections" into the research budget can have an ameliorating effect on the potential to successfully increase the research income. The World Bank SAL initiative helped at the very beginning, but it is not a viable choice for more developed countries, as the World Bank only offers this kind of help to less developed ones. Furthermore, most of the Eastern European countries are indebted to an extent that they cannot afford to take much additional loans. Another possibility is the upcoming Framework Programme Horizon 2020 of the European Union. Its principle to distribute financial support based exclusively on scientific excellence should not be changed, and a juste retour approach would certainly not be justified. However, too narrow a focus on 'research excellence' can overshadow the benefits of full-scale involvement of the new Member States in the Framework Programmes and this should not be neglected either (EC 2010). A possible method to increase participation of the less favoured region is designing funding measures from cohesion policy instruments, specifically to increase the research potentials of HEIs. In order to help creating synergy between funds, the restrictive logic in ESF and ERDF might be softened; the possibility of combining funds from different sources (national budgets, structural funds and other international sources) could contribute significantly to bridging the existent resource gaps in Eastern European R\&D projects. Another "softening" that could help would be the exemption of at least the higher education sector from the strict limitations of allocating structural funds into the most developed Central Hungarian Region, and similarly other regions in the same situation. (NUTS2 regions Prague and Central Bohemia share the same problem.)

To overcome the regional R\&D imbalance, external sources are, of course, not sufficient. Governments in the region should be determined to make efforts into this direction. The amelioration of the research potential is not only a question of subsidies (even if they are necessary to initiate development), but a 
research-friendly legal environment can also be of great help. In addition to initial budgetary help that should concentrate on increasing the potential of research excellence, legal measures to facilitate the support from third parties is also necessary. A concerted effort from the European Union, the ERC and national authorities could be the best guarantee in this less favoured region for the institutions with distinguished traditions of achievement in science not to lose their scientific potential. This would coincide with the goals of the Horizon 2020 program as well; to use the full potential of the new Member States in increasing EU competitiveness over other regions of the world.

Open Access This chapter is distributed under the terms of the Creative Commons Attribution Noncommercial License, which permits any noncommercial use, distribution, and reproduction in any medium, provided the original author(s) and source are credited.

\section{References}

Act CCIV. (2011). Higher education. http://english.szolfportal.hu/images/prospective_student/act_ cciv_of_2011_on_higher_education.pdf

Central Budgets. (2006-2013). Annual acts on the central budget of Hungary (in Hungarian). All Accessed 15 Sept 2014. Act CCXXVII. of 2006 on the 2007 central budget of Hungary (http:// net.jogtar.hu/jr/gen/hjegy_doc.cgi?docid=A0600127.TV). Act CLXIX. of 2007 on the 2008 central budget of Hungary (http://net.jogtar.hu/jr/gen/hjegy_doc.cgi?docid=A0700169.TV). Act CII. of 2008 on the 2009 central budget of Hungary (http://net.jogtar.hu/jr/gen/hjegy_doc. cgi?docid=A0800102.TV). Act CXXX. of 2009 on the 2010 central budget of Hungary (http:// www.complex.hu/kzldat/t0900130.htm/t0900130.htm). Act CLXIX. of 2010 on the 2011 central budget of Hungary (http://www.complex.hu/jr/gen/hjegy_doc.cgi?docid=A1000169. TV). Act CLXXXVIII. of 2011 on the 2012 central budget of Hungary (http://net.jogtar.hu/jr/ gen/hjegy_doc.cgi?docid=A1100188.TV). Act CCIV. of 2012 on the 2013 central budget of Hungary (http://net.jogtar.hu/jr/gen/hjegy_doc.cgi?docid=A1200204.TV).

Central Budget. (2014). Act CCXXX. of 2013 on the 2014 central budget of Hungary (http://net. jogtar.hu/jr/gen/hjegy_doc.cgi?docid=A1300230.TV).

Dmitrishin, A. (2013). Deconstructing distinctions. The European university in comparative historical perspective, entremons. UPF. Journal of World History, 2013(5), 1-18.

EC. (2010). Interim evaluation of the seventh framework programme-report of the expert group. Brussels: European Commission.

Kutatóintézet, H. (2013). Evaluation of recent programs for the higher education I (in Hungarian). pp. 61-66. http://palyazat.gov.hu/a_felsooktatast_celzo_programok_ertekelese

Humboldt, W. (1810). On the internal and external organization of the higher scientific institutions in Berlin (Thomas, Dunlap, Trans.). In W. Hagen (Ed.), From absolutism to Napoleon (16481815) (Vol. 2). Washington, DC: German History in Documents and Images, German Historical Institute. Retrieved from www.germanhistorydocs.ghi-dc.org

Kotán, A., \& Polónyi, I. (2003). The role of the World Bank in the development of Hungarian higher education (in Hungarian). Educatio, 2003(1), 33-50.

MPS. (2012). Teaming for excellence-Building high quality research across Europe through partnership. Munich.

NIO. (2014). Supporting international relations through evaluation of support schemes facilitating Hungary's participation in FP7. Retrieved from http://www.nih.gov.hu/strategiaalkotas/ legfrissebb-kiadvanyaink/elkeszult-hazai-fp7

OECD. (2011). Education at a Glance 2011: OECD Indicators, OECD Publishing. 
Paletschek, S. (2001). The invention of Humboldt and the impact of national socialism: The German university idea in the first half of the twentieth century. In Margit Szöllösi-Janze (Ed.), Science in the Third Reich. Oxford: Berg.

Rácz, K. (2010). The autonomy of university in Hungary between 1848 and 1945 (in Hungarian). Múltunk, 2010(1), 62-82.

Ridder-Symoens, H. (1992-2010). A History of the University in Europe (Vol. I-IV). Cambridge: Cambridge University Press.

Salmi, J., \& Hauptman, A. M. (2006). Innovations in tertiary education financing: A comparative evaluation of allocation mechanisms. Washington DC: The World Bank.

SROP. (2007-2013). Social renewal operational programme 2007-2013 (in Hungarian; Társadalmi Megújulás Operatív Program 2007-2013). http://www.nfu.hu/download/2736/ TAMOP_adopted_hu.pdf

Széll Kálmán Terv. (2011). Cooperation against the national debt, Budapest (in Hungarian). http:// www.polgariszemle.hu/app/data/szellkalmanterv.pdf

UN. (1966). International covenant on economic, social and cultural rights. New York: Entry into force 3 January 1976.

Wittrock, B. (1993). The modern university: The three transformations. In S. Rothblatt \& B. Wittrock (Eds.), The European and American university since 1800 (pp. 303-362). Cambridge: Cambridge University Press.

Woodhall, M. (2007). Funding higher education: The contribution of economic thinking to debate and policy development. Washington DC: The World Bank. 